\title{
Indução de embriogênese somática em diferentes explantes de aveia (Avena sativa L.)
}

\author{
Somatic embryogenesis induction in different explants of oat (Avena sativa L.)
}

\author{
Noryam Bevian Bispo ${ }^{\mathrm{I}}$ Magali Ferrari Grando ${ }^{\mathrm{I}}$ Lizete Augustin $^{\mathrm{I}}$ Marilei Suzin $^{\mathrm{I}}$
}

\section{- NOTA -}

\section{RESUMO}

Três experimentos foram conduzidos com o objetivo de avaliar o potencial de formação de calos embriogênicos de três tipos de explantes de aveia branca (Avena sativa L.) (embrião imaturo, embrião maturo e segmentos de coleóptilo). Cada experimento foi conduzido com um dos explantes, cinco cultivares ("UPF15”, “UPF16”, “UPF18”, “UPFA20” $e$ "OR3”) e dois meios de indução de calos $\left(M 1=M S+2 m g L^{-1}\right.$ de 2,4-D e $\left.M 2=M S+2 m g L^{-1} 2,4-D+1 m g L^{-1} B A P\right)$, sendo avaliadas as freqüências de calos embriogênicos aos 60 dias de cultivo, massa fresca (mg) aos 90 e 120 dias e taxa de crescimento dos mesmos durante um período de 30 dias. Foi observada a influência do genótipo sobre as freqüências de calos somente quando utilizado o explante embrião imaturo. O fator meio não teve influência sobre a freqüência de calos em nenhum dos explantes testados. $\mathrm{O}$ embrião maturo não se mostrou adequado para indução de embriogênese somática em aveia. Os explantes coleóptilo e embrião imaturo apresentaram uma capacidade embriogênica similar, produzindo 24 e $29 \%$ de calos embriogênicos, respectivamente. No entanto, o coleóptilo pode ser considerado o explante ideal devido à independência genotípica, à alta taxa de crescimento de calos (328\% em 30 dias), à fácil disponibilidade e à rapidez de obtenção.

Palavras-chave: Avena sativa L.; cultura de tecidos; embriogênese somática.

\section{ABSTRACT}

Three experiments were carried out to evaluate the embryogenic callus formation potential of three types of explants in oat (Avena sativa L.) (immature embryo, mature embryo and coleptile segments). Each experiment was conduced with one explant, five cultivars (UPF15, UPF16, UPF18, UPFA20 and OR3) and two induction callus medium (M1 = MS + $24-$ $D$ and $M 2=M S+24-D+B A P)$, being analyzed the frequency of embryogenic calli at 60 days of cultivation, callus fresh weight (mg) at 90 and 120 days and callus growth rate during 30 days period. The influence of genotype on the embryogenic callus frequency was detected only when using the immature embryo explant. The culture medium did not influence the frequency of callus in any of the three tested explants. The mature embryo was not suitable for the induction of oat somatic embryogenesis. The coleoptile and immature embryo explants present a similar embryogenic capacity, producing 24 and $29 \%$ of embryogenic calli, respectively. However, the coleoptile can be considered the ideal explant due to its genotypic independence, high embryogenic callus growth rate (328\% in 30 days), as well as easy and quick availability.

Key words: Avena sativa L.; tissue culture; somatic embryogenesis.

A aveia branca (Avena sativa L.) é uma importante alternativa para o cultivo de inverno no Sul do Brasil. Para alguns caracteres de importância agronômica, a variabilidade genética é restrita e a indução de mutações in vitro pode ampliar o potencial de ganhos genéticos nessa cultura. Alterações genéticas podem ocorrer durante o cultivo prolongado de calos in vitro. GRANDO et al. (1997) e AUGUSTIN et al. (2000) induziram alterações positivas e herdáveis em nível fenotípico e molecular através do cultivo de calos embriogênicos em aveia. A embriogênese somática também tem sido útil na regeneração de plantas transgênicas em aveia (TORBERT et al; 1998).

Em cultivares brasileiras de aveia, foram obtidas plantas in vitro a partir de calos induzidos de diferentes explantes, entre eles, sementes maduras (LAMB et al., 2002; GRANDO et al., 2004a), embriões

IFaculdade de Agronomia e Medicina Veterinária (FAMV), Universidade de Passo Fundo (UPF), CP 611, 99001-970, Passo Fundo, RS, Brasil. E-mail: magali@upf.br. *Autor para correspondência. 
imaturos (GRANDO et al., 1993) e coleóptilos (LAMB \& MILACH, 2001). O tipo de calo e o potencial de regeneração podem ser influenciados por fatores como meio de cultura, genótipo e explante (BHASKARAM \& SMITH, 1990; GRANDO et al., 1993). Embora o embrião imaturo seja o explante mais utilizado para iniciar a cultura de tecidos em monocotiledôneas, a utilização de explantes alternativos, como embriões maturos e coleóptilos, podem acelerar o processo de indução de variação somaclonal, uma vez que os mesmos podem ser disponibilizados em todas as épocas do ano.

Esse trabalho foi realizado no Laboratório de Biotecnologia Vegetal da FAMV/UPF e teve como objetivo avaliar o potencial de formação de calos embriogênicos a partir do cultivo de três diferentes explantes em cultivares brasileiras de aveia branca, em dois meios de cultura.

Foram realizados três experimentos, sendo que em cada um foi avaliado um tipo de explante, (embrião imaturo, embrião maturo e segmento de coleóptilo). Para todos os experimentos, foram utilizadas as cultivares “UPF15”, “UPF16”, “UPF18”, “UPFA20” e "OR3", cultivadas em telado e dois meios de indução de calos (M1 = MS (MURASHIGE \& SKOOG, 1962) + 2mg L ${ }^{-1}$ de 2,4-D (Ácido 2,4-diclorofenoxiacético) + 30g $\mathrm{L}^{-1}$ de sacarose $+6 \mathrm{~g} \mathrm{~L}^{-1}$ de ágar; $\mathrm{M} 2=\mathrm{M} 1$ acrescido de $1 \mathrm{mg} \mathrm{L}^{-1}$ de BAP (6-Benzilaminopurina)). A dose de 2,4$\mathrm{D}$ foi adotada em função de resultados obtidos com embriões imaturos por GRANDO et al. (1993).

Para obtenção dos embriões zigóticos imaturos, cariopses no estádio de grão leitoso foram desinfestados e os embriões imaturos (2 a 3mm) excisados foram cultivados nos meios de indução. Para o experimento de embriões zigóticos maturos, cariopses maturos foram descascados, desinfestados e os embriões excisados foram cultivados in vitro. Os segmentos de coleóptilos foram obtidos de cariopses maturos germinados em meio MS, por cerca de uma semana. Coleóptilos com 4,0 a 7,0cm de comprimento foram seccionados na porção basal, de forma a obter segmentos de $2 \mathrm{~mm}$, dentro dos quais estava o meristema apical. Todos os explantes foram subcultivados para meio fresco a cada 30 dias e as culturas mantidas em câmara de crescimento no escuro, a $28 \pm 2^{\circ} \mathrm{C}$.

As variáveis analisadas em cada experimento foram a freqüência de calos embriogênicos aos 60 dias de cultivo, a massa fresca (mg) de calos aos 90 e 120 dias e a taxa de crescimento de calos embriogênicos, expressa em percentagem, em 30 dias (correspondente a um ciclo de cultivo no período dos 90 aos 120 dias). Para cada explante estudado, utilizou- se o delineamento inteiramente casualizado com arranjo fatorial cinco (genótipos) $\mathrm{x}$ dois (meios de cultura) e quatro repetições, sendo a unidade experimental uma placa de Petri com seis explantes. Os dados de freqüência de calos foram transformados por arcoseno de $\mathrm{X}+1$ e submetidos à análise de variância, e as médias comparadas pelo teste de Tukey $(\mathrm{P} \leq 0,05)$. Na análise comparativa dos experimentos, os dados com relação à freqüência, à massa fresca e à taxa de crescimento dos calos embriogênicos foram comparados utilizando a média \pm 1 desvio padrão.

No experimento com embriões zigóticos imaturos, observou-se a influência do genótipo na freqüência de calos embriogênicos $(\mathrm{P}=0,0003)$, onde a cultivar “OR3” produziu a mais alta freqüência deste tipo de calo (66,7\%), diferindo estatisticamente das demais (Tabela 1). Em cereais, tem sido demonstrado que o genótipo desempenha um papel significativo na iniciação de culturas embriogênicas (BHASKARAN \& SMITH,1990). Em genótipos sul-brasileiros de aveia, GRANDO et al. (1993) observaram uma variação de 0 a 37\% na produção de calos a partir de embriões imaturos.

A resposta diferencial entre os genótipos pode ser explicada pelas variações nos níveis de hormônios endógenos, bem como pela expressão de genes que codificam receptores hormonais (CLOSE \& GALLAGHER-LUDEMAN, 1989). Segundo GALIBA et al. (1986), um sistema poligênico pode estar envolvido na determinação da capacidade de indução de calos e da regeneração de plantas.

Quando foram utilizados embriões maturos, não foi observada influência de nenhum dos fatores estudados (genótipo e meio) sobre as freqüências de calos embriogênicos. Em média, a freqüência observada foi de 1,9\%, variando de 0\% (UPF16) a 3,0\% (UPF18).

Tabela 1 - Freqüência de calos embriogênicos obtidos a partir de embriões zigóticos imaturos de cinco cultivares de aveia após 60 dias de cultivo, em dois meios de indução de calos $\left(\mathrm{M} 1=\mathrm{MS}+2 \mathrm{mg} \mathrm{L}^{-1}\right.$ de 2,4-D e M2= M1 acrescido de $1 \mathrm{mg} \mathrm{L}^{-1}$ de BAP)

\begin{tabular}{lc}
\hline Cultivares & $\begin{array}{c}\text { Média de calos } \\
\text { embriogênicos (\%) }\end{array}$ \\
\hline OR3 & $66,7 \mathrm{a}$ \\
UPFA20 & $30,0 \mathrm{~b}$ \\
UPF16 & $23,7 \mathrm{~b}$ \\
UPF18 & $17,4 \mathrm{~b}$ \\
UPF15 & $11,7 \mathrm{~b}$ \\
\hline
\end{tabular}

Médias seguidas de mesma letra não diferem pelo teste de Tukey a $5 \%$ de probabilidade de erro $(\mathrm{P} \leq 0,05)$.

Ciência Rural, v.37, n.3, mai-jun, 2007. 
Baixa freqüência de calos e ausência de efeito genotípico foi observada anteriormente em aveia, com o mesmo explante, por LAMB et al. (2002).

A freqüência de calos embriogênicos obtida de segmentos de coleóptilo contendo meristemas apicais também não foi influenciada pelos fatores genótipo e meio. Porém, diferentemente do observado em embriões maturos, o coleóptilo foi mais eficiente na produção de calos. Em média, 24,1\% dos segmentos de coleóptilos produziram calos embriogênicos, variando de 7,1\% na “UPF15” a 36,7\% na “OR3”. GRANDO et al. (2004), utilizando os mesmos genótipos de aveia, observaram média similar e ausência de efeito genotípico. O comportamento diferencial dos explantes quanto à presença do efeito genotípico na resposta embriogênica poderia ser explicado por vários fatores, como grau de diferenciação, determinação e competência do tecido, níveis hormonais endógenos e estádio do desenvolvimento do explante.

A presença da citocinina BAP no meio de cultura não teve efeito sobre a embriogênese nos diferentes genótipos e explantes de aveia testados. Entretanto, GRANDO et al. (2001) observaram que o uso de BAP em combinação com auxina 2,4-D resultou num aumento de 20 vezes na freqüência de calos embriogênicos de sementes maturas de Paspalum notatum.

Embora a homogeneidade das variâncias não tenha permitido a análise conjunta dos três experimentos em relação às freqüências de calos embriogênicos, é possível comparar os resultados obtidos com os três explantes. As freqüências médias de calos de embriões imaturos (29,1\%) e coleóptilos (24,1\%) foram superiores à freqüência obtida de embriões maturos (1,9\%) (Tabela 2). Porém, um fato negativo observado na utilização do embrião imaturo como explante foi a influência do genótipo na resposta embriogênica in vitro. $\mathrm{O}$ efeito do tipo e idade do explante de gramíneas na resposta in vitro tem sido relatado por vários autores. Tais diferenças podem refletir a variação na concentração endógena de fitohormônios, na produção de receptores hormonais e na expressão de genes envolvidos na embriogênese (CLOSE \& GALLAGHER-LUDEMAN, 1989). Ainda, explantes mais jovens respondem melhor devido ao fato de apresentarem crescimento rápido, o que é essencial para iniciar as culturas.

A massa fresca e a taxa de crescimento de calos são importantes para a determinação da capacidade de crescimento e para a manutenção dos mesmos. Valores inferiores de massa fresca foram observados em calos obtidos de embrião maturo e taxas superiores de crescimento durante um ciclo de subcultivo foram observadas em calos oriundos de coleóptilos (327,7 \%) (Tabela 2).

Conclui-se que o tipo de explante e o genótipo utilizado para iniciar o cultivo in vitro de aveia influenciam na freqüência de calos embriogênicos. A influência genotípica só é observada quando se utiliza o embrião imaturo como explante. Já a adição de BAP no meio de indução não tem influência positiva sobre a freqüência desse tipo de calo. O coleóptilo pode ser considerado o explante ideal para indução de embriogênese somática em aveia devido à alta freqüência de calos formados, à alta taxa de crescimento dos mesmos, à ausência de influência genotípica, além da disponibilidade durante o ano e da rapidez no isolamento do mesmo.

\section{AGRADECIMENTOS}

Os autores agradecem a bolsa de iniciação científica disponibilizada pelo CNPq.

Tabela 2 - Freqüência média de calos embriogênicos, amplitude de variação de médias de tratamentos e influência dos fatores cultivar e meio(+= influência do fator; - = ausência de influência do fator) sobre as freqüências dos calos obtidos nos três explantes, aos 60 dias, bem como massa fresca de calos individuais ( $\mathrm{mg}$ ) observados aos 90 e 120 dias de cultivo e taxa de crescimento no mesmo período

\begin{tabular}{llllcccc}
\hline & \multicolumn{3}{c}{ Calos embriogênicos } & & \multicolumn{2}{c}{ Avaliação do crescimento de calos embriogênicos } \\
\hline \multicolumn{1}{c}{ Explante } & Média (\%) & Variação (\%) & EG & EM & $\begin{array}{l}\text { Massa fresca aos } \\
\text { 90dias (mg) }\end{array}$ & $\begin{array}{l}\text { Massa fresca aos } \\
120 \text { dias (mg) }\end{array}$ & $\begin{array}{l}\text { Taxa de } \\
\text { crescimento (\%) }\end{array}$ \\
Embrião imaturo & 29,1 S & $11,7-66,7$ & + & - & 0,21 & 0,53 & 269,5 \\
Embrião maturo & $1,9 \mathrm{I}$ & $0-3,0$ & - & - & 0,06 I & $0,29 \mathrm{I}$ & 241,5 \\
Coleóptilo & 24,1 S & $7,1-36,7$ & - & - & 0,17 & 0,45 & $327,7 \mathrm{~S}$ \\
Média & 18,36 & & & & 0,15 & 0,42 & 279,57 \\
Desvio padrão & 14,47 & & & & 0,08 & 0,12 & 43,97 \\
\hline
\end{tabular}

EG= Efeito genotípico; EM= Efeito de meio

Média + desvio padrão = superior (S)

Média - desvio padrão $=$ inferior $(\mathrm{I})$ 


\section{REFERÊNCIAS}

AUGUSTIN, L. et al. Agronomic, cytogenetic, and isoenzimatic characterizations of oat somaclones. Genetics and Molecular Biology, Ribeirão Preto, v.23, n.3, p.649-660, 2000.

BHASKARAN S; SMITH RH. Regeneration in cereal tissue culture: a review. Crop Science, Madison, v.30, p.1328-1336, 1990.

CLOSE, K.R.; GALLAGHER-LUDEMAN, L.A. Structureactivity relationships of auxin-like plant growth regulators and genetic influences on the culture induction responses in maize (Zea mays L). Plant Science, Ireland, v.61, p.245252, 1989.

GALIBA, G. et al. Substitution analysis of plant regeneration from callus culture in wheat. Plant Breeding, Berlin, v.97, p.261-263, 1986

GRANDO, M.F. et al. Indução de calos e regeneração de plantas em três genótipos de aveia. Revista Brasileira de Fisiologia Vegetal, Londrina, v.5, n.2, p.139-144, 1993.

GRANDO, M.F. et al. Avaliação das características agronômicas em populações $R_{3}$ de aveia geradas pelo cultivo de tecidos. Pesquisa Agropecuária Gaúcha, Porto Alegre, v.3, n.2, p.139-145, 1997.
GRANDO, M.F. et al. Optimizing embryogenic callus production and plant regeneration from "Tifton 9" bahiagrass (Paspalum notatum Flügge) seed explants for genetic manipulation. Plant cell, Tissue and Organ Culture, Netherland, v.1, n.10, p.110, 2001.

GRANDO, M.F. et al. Uso de meristema apical como explante para indução de calos embriogênicos em cinco genótipos de aveia. In: REUNIÃO DA COMISSÃO BRASILEIRA DE PESQUISA DE AVEIA, 24., 2004, Pelotas, RS. Anais... Pelotas: UFPEL, 2004. p545-547.

LAMB, C.R.C.; MILACH, S.C.K. Regeneração de plantas a partir de segmentos de base de folhas em aveia. Ciência Rural, Santa Maria, v.31, n.5, p.751-755, 2001.

LAMB, C.R.C. et al. Embriogênese somática e regeneração de plantas a partir de embrião maduro em aveia (Avena sativa L.) In: BRAMMER, S.P.; IORCZESKI, E.J. Atualização em técnicas celulares e moleculares aplicadas ao melhoramento genético vegetal. Passo Fundo: Embrapa Trigo, 2002. p.349-362.

MURASHIGE, T.; SKOOG, F. A revised medium for rapid growth and bio assays with tabacco tissue cultures. Physiologia Plantarum, Sweden, v.15, p.473-497, 1962.

TORBERT et al. Genetically engineering elit oat cultivars. Crop Science, Madison, v.38, p.1685-1687, 1998. 